\title{
Flattening the Curve, Constitutional Crisis and Immigrants' Rights Protections: The Case of Israel
}

\author{
Tally Kritzman-Amir ${ }^{1,2,3 *}$ \\ ${ }^{1}$ Department of Sociology, Harvard University, Cambridge, MA, United States, ${ }^{2}$ Tally Amir, Cambridge, MA, United States, \\ ${ }^{3}$ Boston University School of Law, Boston, MA, United States
}

Despite being a small and relatively secluded country, managing the COVID-19 pandemic has so far been quite a challenge for Israel. This contribution seeks to explain how Israel had managed migration and the pandemic amidst a constitutional crisis between February and July 2020.

Keywords: Israel, Immigration and migration, refugees and asylum, migration for employment, family reunification, law and policy, Palestinians, Coronavirus

\section{CLOSING BORDERS}

OPEN ACCESS

Edited by:

Jaya Ramji-Nogales,

Temple University, United States

Reviewed by:

Michael Kagan,

University of Nevada, United States

Itamar Mann

University of Haifa, Israel

*Correspondence:

Tally Kritzman-Amir

tamir@bu.edu;

tamir@fas.harvard.edu

Specialty section: This article was submitted to

Refugees and Conflict,

a section of the journal

Frontiers in Political Science

Received: 06 August 2020

Accepted: 21 October 2020

Published: 28 April 2021

Citation:

Kritzman-Amir T (2021) Flattening the

Curve, Constitutional Crisis and

Immigrants' Rights Protections: The

Case of Israel.

Front. Polit. Sci. 2:592150.

doi: 10.3389/fpos.2020.592150
The first Coronavirus patient was diagnosed in Israel in late February 2020, after having arrived from Italy ${ }^{1}$. This happened days after Israel started prohibiting entry of tourists from countries with high infection rates ${ }^{2}$ and imposed quarantine requirements on Israeli nationals arriving from those countries. Yet despite this measure, in our globalized world, the pandemic penetrated Israel, proving the no matter how self-contained and closed-off states attempt to be, they inevitably maintain a significant degree of interdependence and interconnectedness, and are not able to avoid significant outside influences.

By March 2020, entry restrictions became broader, allowing only entry of nationals and residents ${ }^{3}$ This impacted, for example, the ability to bring in new migrant workers, despite the fact that the Israeli economy is very much dependent on the availability of migrant workers in construction, agriculture, and the care sectors ${ }^{4}$. This also restricted the ability of spouses and children of Israeli citizens who are not nationals themselves to come to Israel in order to be with their family members ${ }^{5}$, and impacting their ability to meaningfully enjoy their right to family life ${ }^{6}$.

${ }^{1}$ Hilay, S., and Alon, A. First Coronovirus Patient in Israel, Arrived from Italy Four Days Ago, YNET (Feb. 27, 2020), https:// www.ynet.co.il/articles/0,7340,L-5685621,00.html. Two persons who contracted the virus but were asymptomatic arrived to Israel before.

${ }^{2}$ Alon, A., and Blumental, I. Israel Will Prevent Entrance of Foreigners Who Stayed in Thailand, Singapore, Macao and Hong Kong, CAlCALIST (Feb. 17, 2020), https://www.calcalist.co.il/local/articles/0,7340,L-3794333,00.html. Some tourists who were diagnosed with the Coronavirus visited Israel and infected locals who interacted with them. Blumental et al. South Koreans Who Contracted Coronavirus Visited Israel, YNET (Feb. 22, 2020), https://www.ynet.co.il/articles/0,7340,L-5682186, 00.html; Ashkenazi, E. The Bus Driver Who Contracted Coronavirus and Was in Severe State Has Recovered: "Toughest Month in My Life", WALla! News (Mar. 30, 2020), https://news.walla.co.il/item/3349605.

${ }^{3}$ Raz-Chaimovich, M. Israel Closed Skies, Globes (Mar. 8, 2020), https://en.globes.co.il/en/article-israels-closed-skies1001321063.

${ }^{4}$ See generally, DRORI, I. FOREIGN WORKERS IN ISRAEL (2009).

${ }^{5}$ Stavrou, D. This Is Discrimination - I Feel Like a Second-Class Citizen Because I Didn't Marry a Jew, HAARETZ (July 6, 2020), https://www.haaretz.com/israel-news/premium.MAGAZINE-in-israel-whoever-isn-t-jewish-doesn-t-getanything-1.8970934.

${ }^{6}$ G.A. Res. 217(III) A, Universal Declaration of Human Rights, art. 16(3) (Dec. 10, 1948); International Covenant on Civil and Political Rights art. 23(1), Dec. 16, 1966, 999 U.N.T.S. 171; International Covenant on Economic, Social and Cultural Rights art. 10(1), Dec. 16, 1966, 993 U.N.T.S. 3. 
Procedures allowing a limited possibility for non-nationals who are family members of Israeli citizens to enter the country for only published in late July, following massive pressure from the Israeli civil society and press ${ }^{7}$.

\section{CONSTITUTIONAL CRISIS, LEADERSHIP CRISIS}

The pandemic outbreak occurred when Israel was also dealing with an unprecedented constitutional crisis $^{8}$. Over the course of 1 year, Israel went through three cycles of elections due to the inability to form a majority government after the two first cycles. The third elections were held after the first Coronavirus patients were diagnosed in Israel, and just a few days before the economy shut down. The crisis of the pandemic deemed so severe to some of the elected officials as to justify breaking multiple election promises and forming a unity government ${ }^{9}$. In the process of shutting down the economy, different parties were holding discussions on possibilities of forming a government, a process that has proven to be challenging in the last few decades in Israel's parliamentary democracy system ${ }^{10}$.

Initially, much of the COVID-19 emergency was thus handled by an interim government, the moral authority of which was met with massive public resistance ${ }^{11}$. The interim government was viewed with suspicion due to both the lack of ability to form a stable new government and the fact that even after the new unity government was formed, several of its ministers were

\footnotetext{
${ }^{7}$ The Population and Immigration Authority, Entry to Israel Policy in the Coronavirus Period (March 19, 2020, update from July 28, 2020) https://www. gov.il/he/departments/news/border_closing_coronavirus_14062020. The policy allowed for some married couples and their children to re-enter Israel "after examination and in exceptional circumstances". However, it seems that the policy was not implemented immediately. Gur David, U. The Skies are Closed and That's It, The State Continues to Deny Thousands of Israelis the Possibility of Reunification with Their Partners and Children, HAMAKOM (July 23, 2020) https://www.hamakom.co.il/post-uriel-no-flights/.

${ }^{8}$ Bar Siman Tov, I. Covid-19 Meets Politics: the Novel Coronavirus as a Novel Challenge for Legislatures, 8 THE THEORY AND PRACTICE OF LEgISLATION 1148 (2020); Ben Sales, Israel Is Going Through a Constitutional Crisis, JEwISH Telegraphic Agency (Mar. 24, 2020), https://www.jta.org/2020/03/24/israel/ israel-is-going-through-a-constitutional-crisis.

${ }^{9}$ See, e.g., Hostovsky Brandeis, T. Israel's Perfect Storm: Fighting Coronavirus in the Midst of a Constitutional Crisis, Verfassungblog (April 7, 2020) https:// verfassungsblog.de/israels- perfect-storm-fighting-coronavirus-in-the-midstof-a-constitutional-crisis/; Mordechay, N., and Roznai, Y. Constitutional Crisis in Israel: Coronavirus, Interbranch Conflict, and Dynamic Judicial Review, VERFASSUNGBLOG (April 8, 2020) https://verfassungsblog.de/constitutionalcrisis-in-israel-coronavirus-interbranch-conflict-and-dynamic-judicial-review/; Sales, B. Israel is Going Through a Constitutional Crisis, ForwARD.COM (March 25, 2020), https://forward.com/fast-forward/442315/israel-is-going-through-aconstitutional-crisis/.

${ }^{10}$ Schneider, T. Gantz: "We Will Establish a Coronavirus Cabinet Which Unfortunately Will Have to Function for a Long Period of Time. The Forum Will Include All Relevant Ministers", GLOBES (Apr. 21, 2020), https://www.globes.co.il/ news/article.aspx?did=1001326095.

${ }^{11}$ Sharvit Baruch, P., and Beeri, O. The Coronavirus Crisis in Israel: When an Epidemic Meets a Political Crisis, INSS INSIGHT No. 1291 (Apr. 2, 2020), https:// www.inss.org.il/publication/coronavirus-and-law- $1 /$ ? offset $=57 \&$ posts $=1349 \&$ type=399; Landau, N. It Is Indeed an Emergency Hour: We Should Not Allow Breach in Our Basic Principals in the Asupices of Coronavirus, HAARETz (Mar. 15, 2020), https://www.haaretz.co.il/health/corona/.premium-1.8675399.
}

facing criminal charges or undergoing criminal investigations, including the Prime Minister Benjamin Netanyahu himself. In addition, the interim government had a somewhat compromised authority to take some of the steps deemed necessary to manage the pandemic ${ }^{12}$.

The constitutional crisis in Israel though was not limited to the executive and legislative branches. This process also occurred as the pressure was mounting on the Israeli judicial system. The right-wing political leadership in Israel delegitimized the Israeli courts on an ongoing basis, looking to pass an override clause to restrict its ability to conduct judicial review of primary legislation. This issue of judicial autonomy and the override clause was one of the issues in the negotiations between the parties which eventually formed the government ${ }^{13}$. It is worth mentioning that much of the legitimacy crisis of the Israeli court system had to do with its display of judicial activism in decisions on asylum policy, namely a series of decisions strike down legislation on immigration detention ${ }^{14}$.

The exposed nerves of the relationships between the different branches of government were once again hit, leading to the eventual intervention of the Israeli High Court of Justice in various issues relating to the relationship between the legislature and the government having to do with the coalition formation process ${ }^{15}$.

Finally, in the midst of this conundrum, Israel announced intentions to annex parts of the West Bank ${ }^{16}$, an act that attracted significant international criticism ${ }^{17}$. While this intention has yet to materialize when this paper was written, this act, which would be a violation of international law, would, in all likelihood, impose another set of constitutional crises in Israel, as well as security issues and international pressures.

\section{EMERGENCY LEGAL FRAMEWORK}

It was in this constitutional atmosphere, Israel was forced to cope with the emerging Coronavirus crisis. The above-mentioned entry and immigration restrictions were, a small part of the picture: Between mid-March and early July Israel applied a mixed

\footnotetext{
${ }^{12}$ Altstein, G. The Coronavirus Drama Is Too Big for a One Man Show, CAlCAlist (Mar. 16, 2020), https://www.calcalist.co.il/local/articles/0,7340,L3801341,00.html.

${ }^{13}$ Shemesh, M. Netanyahu Demands: NotwithStanding Clause to Secure His Service and Prevent Supreme Court Intervention, KAN (Apr. 12, 2020), https://www.kan. org.il/item/?itemid=69534.

${ }^{14}$ Weill, R., and Kritzman-Amir, T. Between Institutional Survival and Human Rights Protection: Adjudicating Landmark Cases of African Undocumented Migrants in Israel in a Comparative and International Context, 41 U. PENN. J. INT'L L. 43 (2019).

${ }^{15}$ Wootliff, R. and TOI Staff. High Court Orders Vote for New Knesset Speaker to go Ahead Thursday, Times of IsRAel (Mar. 26, 2020), https://www.timesofisrael. com/high-court-orders-vote-for-new-knesset-speaker-to-go-ahead-thursday/.

${ }^{16} \mathrm{Al}$ Jazeera and News Agencies. Netanyahu Discusses Annexation Plan with Gantz: Report, AL JAZEERA (June 18, 2020), https://www.aljazeera.com/news/2020/06/ netanyahu-discusses-annexation-plan-gantz-report-200618083806812.html.

${ }^{17}$ Tidey, A. More Than 1,000 European MPs Call for Israel Annexation to Be Halted and Warn of 'Consequences', EURONEWs (June 24, 2020), https://www.euronews. com/2020/06/24/more-than-1-000- european-mps-call-for-israel-annexationto-be-halted-and-warn-of-consequen.
} 
approach of acute emergency measures enforcing closures ${ }^{18}$, restricting economic activity ${ }^{19}$, an extremely strict approach to physical distancing ${ }^{20}$, alongside with minimal economic assistance to persons whose financial stability was compromised due to the resulting changes in the labor market ${ }^{21}$.

Initially, the reliance on emergency regulations was almost inevitable since Israel did not have a functioning parliament or parliamentary committees in March, and its health laws were ill-fitted to introduce the restrictions necessary to deal with the public health situation at hand ${ }^{22}$. However, this behavior pattern institutionalized, and resulted in a wide-scale longterm emergency regulatory crisis. As research by Nir Kosti demonstrates, in the first 3 months of the attempts to address the Coronavirus pandemic, the Israeli Government quickly passed 38 emergency regulations, and amended them 64 times $^{23}$. This unusually high number of emergency regulations was dramatically high and unprecedented even for a country like Israel. Israel has been in a constant state of general emergency since 5 days after declaring its independence 1948, and has since normalized the use of emergency regulations, but never were so many of them enacted in such a short period of time ${ }^{24}$. Those regulations were passed in a quick, secretive manner, without much public or parliamentary debate, and without outlining any clear considerations or explaining the scientific basis for the imposed restrictions. The emergency regulations covered restrictions on freedom of movement, on the labor market, and on the operation of the court system; introduction of physical distancing requirements; tracing of persons tested positive with the virus; and management of the economic crisis. The emergency regulation seemed trivial, and were treated by the Israeli Prime Minister Netanyahu as a necessary measure

\footnotetext{
${ }^{18}$ Kaplan Sommer, A. Explained: Shutdown, Curfew in Israel's Toughest Coronavirus Restrictions to Date, HAARETz (Apr. 7, 2020), https://www. haaretz.com/israel-news/new-coronavirus-guidelines-edging-israel-closer-tototal-lockdown-1.8683889; but see Ruth Eglash and Steve Hendrix, Israeli Lawmakers Move Quickly on New Government After Court Endorses Netanyahu's Coalition, WASHINGTON POST (May 7, 2020), https://www.washingtonpost.com/ world/middle_east/israel-high-court-allows-netanyahu-to-form-a-governmentdespite-indictment/2020/05/07/82dd0dde-901e-11ea-9322-a29e75effc93_story. html.

${ }^{19}$ Schneider, T., and Ashkenazi, S, The Next Step on the Agenda: Wide Lockout of the Market, GLOBES (Mar. 13, 2020), https://www.globes.co.il/news/article.aspx? did $=1001321717$.

${ }^{20}$ Global Legal Monitor. Israel: COVID-19 Social Distancing Requirements Tightened, Library OF CONGRESS (Apr. 1, 2020), https://www.loc.gov/law/ foreign-news/article/israel-covid-19-social-distancing-requirements-tightened/.

${ }^{21}$ Surkes, S. Israel's Coronavirus Aid Package Only Half That of Similar Developed Nations, Times OF IsRAEL (May 7, 2020), https://www.timesofisrael.com/israelscoronavirus-aid-package-only-half-that-of-similar-developed-nations/.

${ }^{22}$ Kosti, N. Emergency Regulations: Contemporary and Historic Look, ICONS-IL-BLOG (July 7, 2020), https://israeliconstitutionalism.wordpress.com/ 2020/07/07/\%d7\%aa\%d7\%a7\%d7\%a0\%d7\%95\%d7\%aa-\%d7\%a9\%d7\%a2\%d7 \%aa- \%d7\%97\%d7\%99\%d7\%a8\%d7\%95\%d7\%9d-\%d7\%9e\%d7\%91\%d7\%98\%d7\%a2\%d7\%9b\%d7\%a9\%d7\%95\%d7\%95\%d7\%99-\%d7\%95\%d7\%94\%d7\%99 \%d7\%a1\%d7\%98\%d7\%95\%d7\%a8\%d7\%99-\%d7\%a0/?fbclid=IwAR2bd3ulM3OucJzx1bFwf9AR_AYfg7q2XFa39Na8IPnkN0tm-uYkaU6RFg.

${ }^{23} I d$.

${ }^{24}$ Id.; Margalit, L. Emergency Powers and Parliamentary Monitoring in the Coronavirus Crisis: Comparative Survey, ISRAEL DEMOCRACY INSTITUTE (May 7, 2020), https://www.idi.org.il/articles/31524?fbclid= IwAR2xdN3X_rBvEzSspcS4wmkxKaqRicQxlr7A_tK8tWIVp8EV0WLYRCVtaHM
}

to overcome the "bureaucracy" of passing legislation in the Israeli Parliament ${ }^{25}$.

Nevertheless, this massive use of emergency regulations did not go unnoticed. The Attorney General of the State of Israel criticized the massive use of the emergency regulations, calling to rely on primary legislation to the extent possible ${ }^{26}$. Some members of the Israeli public demonstrated against the use of the regulations ${ }^{27}$. Finally, several Israeli human rights organizations petitioned against some of those regulations, and some of those petitions were successful in the Israeli High Court of Justice ${ }^{28}$.

\section{NEVERTHELESS, IMMIGRATION}

Inevitably, despite the pandemic, the vast emergency measures and the above-mentioned constitutional crisis, the issue of immigration could not be sidelined in Israel, even in a time like this.

Just like in non-pandemic days, the characteristics of Israel's immigration policy are a big part of the character of the state. It is easy to understand the Israeli immigration and asylum regime if we imagine a spectrum. On one end of the spectrum there are immigrants who are included in the Israeli society and the welfare state and receive access to status. On the other end are those migrants who are excluded from Israel, and thus are not able to acquire status or access to the Israeli welfare state. I will provide a short overview of the meaningful categories of migrants in the Israeli immigration regime and explain how the challenges of the pandemic have met each of the particular categories.

\section{Jewish Migrants or Olim and Family Members of Israeli Citizens}

On the inclusive end of the spectrum are Jewish migrants and their relatives who migrate under the Law of Return ${ }^{29}$. The most fundamental component of Israel's immigration laws, the general premise of which is that "Every Jew has the right to come to this country as an oleh [an ascender, Jewish new comer-t.k.a]" 30 . This notion corresponds to the nature of Israel as a Jewish and democratic state, as proclaimed in its

\footnotetext{
${ }^{25}$ PM Netanyahu's Statement to the Media, Israel Ministry of Foreign AfFAIRS (July 2, 2020), https://mfa.gov.il/MFA/PressRoom/2020/Pages/PMNetanyahu-s-statement- to-the-media-2-July-2020.aspx.

${ }^{26}$ Gorali, M. Mandelblit to Netanyahu: Promote Legislation to Coping with Coronavirus Instead of Emergency Regulations, CALCALIST (Apr. 6, 2020), https:// www.calcalist.co.il/local/articles/0,7340,L-3806478,00.html.

${ }^{27}$ Toi Staff. Hundreds protest against Netanyahu, contentious emergency virus bill in Tel Aviv, The Times of Israel (June 5, 2020), https://www.timesofisrael.com/ hundreds-protest-against-netanyahu-contentious-emergency-virus-bill-in-telaviv/.

${ }^{28}$ Annul Emergency Regulations Allowing Tracking Upon Citizens, Association FOR CIVIL RIGHTS IN ISRAEL (Apr. 6, 2020), https://www.acri.org.il/post/_387; After Adalah's Petition to the Supreme Court: Netanyahu Repeals Emergency Regulations That Allowed Employers to Dismiss Pregnant Women During Coronavirus Period, ADALAH (Apr. 17, 2020), https://www.adalah.org/he/content/ view/9988.

${ }^{29}$ Law of Return, 5710-1950, SH No. 51 p. 159.

${ }^{30}$ Id. art. 1 .
} 
declaration of independence ${ }^{31}$ and in Israel's basic laws $s^{32}$, which translates into an effort to maintain a Jewish majority ${ }^{33}$. Under the corresponding naturalization norms, the Nationality Law, citizenship is granted automatically to those who immigrate to Israel under the Law of Return. Non-returnees have a limited ability to acquire citizenship ${ }^{34}$.

After the pandemic outbreak, Israeli authorities announced an increase in the applications for oleh status, though it is unclear how significant this increase is. Numbers ranged from a two percent increase in Aliya to up to a fifty percent increase ${ }^{35}$. Some have argued that the Coronavirus outbreak is an opportunity to induce aliya - Jewish migration or return - to Israel, given the economic crisis in many countries, which also hit some of the Jewish communities ${ }^{36}$. At the same time, others provided data supporting the conclusion that aliya to Israel will actually decrease $^{37}$. This hope of potential aliya was celebrated by many in Israel. Israel, in fact, encouraged the arrival of some Jewish non-citizens, with the hope of serving them as the Jewish home. In July, the Israeli government approved the massive arrival of thousands of Ultraorthodox students under relaxed quarantine rules $^{38}$. This created a situation which some might perceive as an anomaly, in which persons who are outsiders to the national community (but insiders to the ethnic-religious community) are allowed to enter the country even at a high cost for public health, while the entry of insiders to the national community (such as non-citizen nuclear family members of nationals, who are ethnicreligious outsiders by virtue of being non-Jewish) is restricted ${ }^{39}$.

\footnotetext{
${ }^{31}$ Declaration of the Establishment of the State of Israel, 1 L.S.I. 3 (1948).

${ }^{32}$ See, e.g., Basic Law: Human Dignity and Liberty, $\$ 1$, SH No. 1391 p. 150 (according to which "[t]he purpose of this Basic Law is to protect human dignity and liberty, in order to establish in a Basic Law the values of the State of Israel as a Jewish and democratic state.").

${ }^{33}$ On the connection between being an Israeli state and maintaining a Jewish majority in Israel, see the Interim Report of the Advisory Committee on Israel's Immigration Policy 3-6 (Feb. 7, 2006) [in Hebrew] (copy on file with author). This committee was appointed by the former minister of interior and headed by Prof. Amnon Rubinstein.

${ }^{34}$ Nationality Law, 5712-1952, SH No. 95 p. 146.

${ }^{35}$ Jean, C. $20 \%$ Increase in Demand for Aliyah Following the Coronavirus Crisis, JeRUSALEM POST (May 21, 2020), https://www.jpost.com/diaspora/20-percentincrease-in-demand-for-aliyah-following-the-coronavirus-crisis-628759; 20\% Increase in Demand for Aliyah Following the Coronavirus Crisis, Record Number of Olim Landed This Morning in Israel, Ministry of Aliyah and Integration (May 25, 2020), https://www.gov.il/he/departments/news/aliyah_1952020; Yalon, Y. Olim Flight from the U.S. Landed in Israel, ISRAEL HaYOM (June 9, 2020), https://www.israelhayom.co.il/article/769323; Knesset News, Estimations of 50,000 Olim This Year, Almost Twice, and the Ministries Budgets Were Not Enlarged, KNESSET (June 16, 2020), https://main.knesset.gov.il/News/PressReleases/Pages/ press16062020I.aspx.

${ }^{36} \mathrm{Feiglin}, \mathrm{M}$. Coronavirus Is an Opportunity to Complete the Return to Zion in a Big Aliyah Wave, HAARETZ BlOGS (Apr. 27, 2020), https://www.haaretz.co.il/blogs/ radical/BLOG-1.8799555.

${ }^{37}$ Experts Writing. Will the Coronavirus Spread Create Waves of Aliyah and Return to Israel, BIZPORTAL (July 7, 2020), https://www.bizportal.co.il/bizpointsponsored/news/article/781990; Waxman, A. Of the Coronavirus Victims: The Aliyah to Israel Decreased by 42\%, THE MARKER (July 12, 2020), https://www. themarker.com/news/macro/1.8988205.

${ }^{38}$ Amit, H. Thousands of Yeshiva Students to Be Let Into Israel, Under Relaxed Quarantine Rules, HAARETZ (July 26, 2020) https://www.ha-makom.co.il/posturiel-no-flights/.

${ }^{39}$ The entry of family members of citizens was limited to exceptional cases. See: The Entry to Israel Policy during the Period of the Coronavirus
}

Attempts to challenge this inconsistent and discriminatory policy in Court failed, as the Court deferred to the government on this matter, finding that individuals may petition regarding their individual cases rather than challenge the policy in its entirety ${ }^{40}$.

\section{Migrant Workers}

Under the Israeli immigration regime, non-Jews do not hold a right to immigrate to Israel, and their entry to the state is restricted through the Entry to Israel Law ${ }^{41}$. Non-Jewish persons would typically not be able to naturalize in Israel.

Further down from the inclusive end of the spectrum we would find the category of non-Jewish migrant workers. Since the early 1990s Israel has invited migrant workers to enter its territories for employment in agriculture, construction, industry and care sectors for a limited period of time ${ }^{42}$. The migrant workers comprise a significant part of the Israeli labor market and employers became dependent on their available labor ${ }^{43}$. Nevertheless, they are not fully included in the Israeli society and welfare state, are largely isolated and are eligible for only a few of the socio-economic rights and benefits that Israeli nationals enjoy access to ${ }^{44}$. Generally speaking, migrant workers are only rarely perceived in the fully capacity of their humanity, but rather are perceived in terms of their labor force and their utility to their employers.

An overtly simplified perception of the best interest of the employer was the underlying logic of all the policy measures that addressed the rights of migrant workers. Most measures addressed the concerns of the employers in the care sector, where the intimate connection and the pre-existing health conditions of the employers are cause for concern. Despite the mostlyclosed border policy, attempts to freeze entry of labor migration were not completely successful, and eventually the Population and Immigration Authority allowed for migrant workers who left Israel for vacation to return to Israel, subject to quarantine requirements ${ }^{45}$. Later on, newly recruited migrant workers were also allowed to enter Israel to work in the care sector ${ }^{46}$, and

(June 14, 2020), available at: https://www.gov.il/he/departments/news/ border_closing_coronavirus_14062020. This restriction was placed despite the fact that this impacts the right to family life of the Israeli citizens.

${ }^{40} \mathrm{HCJ}$ 5692/20 Helit Kovetski vs. The Minister of Interior (September 9, 2020), available at: https://supremedecisions. court.gov.il/Home/Download?path=HebrewVerdicts\%5C20\%5C820 $\% 5$ C056\%5Ce06\&fileName $=20056820$.E06\&type $=2 \& \mathrm{fbclid}=$ IwAR2xIulxFLYQPMidhSpW67EGVFs8tNgiCV71a1JZZwls4CuFaICLjZBU5X4 [in Hebrew]. HCJ 5628/20 Plia Katner vs. The Ministry of Interior (September 14, 2020) (on file with author) [in Hebrew].

${ }^{41}$ Entry into Israel Law, 5712-1952, SH No. 111 p. 354.

${ }^{42}$ Bartram, D. Foreign Workers in Israel: History and Theory, 32 INT'L MIGRATION REV. 303 (1998).

${ }^{43}$ Natanzon, R., ET AL. ImMigrant WORKERS AND NON-ISRAELIS IN THE ISRAELI LABOR MARKET (2017), http://www.macro.org.il/images/upload/items/ 16423344100905.pdf.

${ }^{44}$ Kritzman-Amir, T. "Otherness" as the Underlying Principle in Israel's Asylum Regime, 42 ISR. L. REV. 306 (2010).

${ }^{45}$ Letter by Inbal Mashash, Foreign Workers Administration Director, Framework for the Entry of Foreign Workers in the Care Sector Who Are Presently Staying in Vacation Outside Israel (May 20, 2020) [on file with author].

${ }^{46}$ The Population and Immigration Authority, Announcement of the Expansion of the Plan to Allow Entry of Migrant Workers in the 
migrant workers in the agriculture sector were also allowed to return to Israel from their vacation ${ }^{47}$.

Various restrictions were temporarily imposed on the ability of migrant workers in the care sector who work in nursing homes ${ }^{48}$. One such restriction was a general prohibition on care workers to leave the nursing home premises, except in unusual circumstances ${ }^{49}$. Additionally, migrant workers were subjected to daily monitoring of their health situation, and required to wear PPA at all times ${ }^{50}$. All considerations of the workers' right to privacy, freedom of movement, and autonomy ${ }^{51}$ were sidelined or utterly disregarded by both risk-averse employers and officials. As physical distancing requirements were eased, and due to intense pressures of migrants' rights NGOs, eventually migrant workers were allowed to leave their workplaces to enjoy some time off. However, they were still barred from staying in shared apartments, in which most of them had stayed in before the pandemic outbreak ${ }^{52}$. This restriction effectively meant that migrant workers were not able to stay outside of their employer's house for more than a few hours at a time, since most were not able to afford renting out their own place. In the tense and stressful situation of coping with a global crisis of massive scale and a demanding job, this restriction was another dimension of difficulty to an already physically and emotionally tasking situation.

\section{Asylum Seekers}

Further down the immigration policy spectrum are asylum seekers. Israel is currently hosting more than thirty thousand asylum seekers, mostly from Eritrea and $\mathrm{Sudan}^{53}$, referred to

Care Sector (July 13, 2020) https://www.gov.il/he/departments/policies/ extending_plan_to_allow_entering_of_caregivers.

${ }^{47}$ The Population and Immigration Authority, Announcement on the Conditions for Application for Allowing the Return of Migrant Workers in the Agriculture Sector Who Left for Vacation in Their Country with Intervisa (July 23, 2020) https://www.gov.il/BlobFolder/policy/ return_application_for_foreign_workers_with_intervisa/he/\%D7\%9B $\% \mathrm{D} 7$ \%A0\%D7\%99\%D7\%A1\%D7\%AA\%20\%D7\%A2\%D7\%95\%D7\%91\%D7\%93\%D7 \%99\%20\%20\%D7\%90\%D7\%99\%D7\%A0\%D7\%98\%D7\%A8\%D7\%95\%D7\%99 \%D7\%96\%D7\%94\%20\%D7\%97\%D7\%A7\%D7\%9C\%D7\%90\%D7\%95\%D7\%AA. pdf.

${ }^{48}$ Gamzu, R. MAgen For OUr Fathers And Mothers 133, art. 11.1.3 (Apr. 20, 2020) https://govextra.gov.il/media/17274/elderly-care-covid19.pdf.

${ }^{49} \mathrm{Id}$. at 133 , art. 11.1.3.1.

${ }^{50} I d$. at 133 , art. 11.1.3.2-5.

${ }^{51}$ Migrant workers are granted the right to privacy, freedom of movement and autonomy under Israeli constitutional law. See Basic Law: Human Dignity and Liberty, SH No. 1391 p. 150. Also, since Israel is a party to the International Covenant on Civil and Political Rights, they are also eligible to those rights under international law. International Covenant on Civil and Political Rights, supra note 7 , art. 12,1 .

${ }^{52}$ Notice for Foreign Workers Who Live in the House of the Patient, Ministry OF HEALTH (May 8, 2020), https://www.gov.il/he/departments/news/080520_01.

${ }^{53}$ Population and Immigration Authority, Foreigners in Israel DATA, EDITION 1/2020 (Apr. 2020), https://www.gov.il/BlobFolder/generalpage/ foreign_workers_stats/he/\%D7\%A0\%D7\%AA\%D7\%95\%D7\%A0\%D7\%99\%20 \%D7\%96\%D7\%A8\%D7\%99\%D7\%9D\%20\%D7\%91\%D7\%99\%D7\%A9\%D7\%A8 \%D7\%90\%D7\%9C\%20\%D7\%A8\%D7\%91\%D7\%A2\%D7\%95\%D7\%9F\%201 \%202020.pdf. The state's authorities and the Court use the term 'infiltrators' to describe the asylum seeking population, but, in our view, a more accurate term would be "asylum seekers," since the latter term focuses more on the purpose of these people's arrival in Israel rather than on the way they reached the country. by the government as "infiltrators." Despite being a party to the Convention and the Protocol since their entry into force, Israel has yet to incorporate its international law obligations to refugees into its domestic law, and has only started conducting Refugee Status Determination (RSD) on its own in $2009^{54}$. Most of the asylum seekers have arrived in Israel since the middle of the first decade of the twenty-first century through its southern, continental border with Egypt in an undocumented manner ${ }^{55}$. Since 2010, many of them were subjected to a difficult journey en route to Israel, which for many included a period of time during which they were held captive by their smugglers, tortured, raped, and enslaved to extort money from their families ${ }^{56}$. In 2013, this border became virtually impossible to cross with the erection of a border fence ${ }^{57}$.

Asylum seekers enjoy a fragile status in Israel, and most are protected from deportation under temporary collective arrangements $^{58}$. Generally speaking, Israel has been applying various means of exclusion on the asylum seeking population, including strict border policies ${ }^{59}$; extended periods of immigration detention for those who enter in an undocumented manner ${ }^{60}$; denial of social and economic rights, as well as political participation ${ }^{61}$; continuous attempts resettlement (voluntarily and forcibly) to third countries ${ }^{62}$; geographical limitations, restricting their ability to work or reside in certain urban areas $^{63}$; heavy taxation ${ }^{64}$; issuance of work permit which do not grant asylum seekers the right to vote, but include an implicit commitment to refrain from enforcing the prohibition to employ them on the employers ${ }^{65}$; extremely low recognition rates $(0.1 \%)^{66}$; and imposition of bureaucratic hurdles and

\footnotetext{
${ }^{54}$ Before that was only partially involved in a hybrid RSD process administered by the United Nations High Commissioner for Refugees (UNHCR). Harel, S. The Asylum Apparatus of Israel: The Process of Transferring the Responsibility for Handling Asylum Applications from the United Nations High Commissioner for Refugees to the State of Israel, in WHERE LEVINSKI MEETS ASMARA: SOCIAL AND Legal Aspects of IsRael's Asylum Policy 43 (Kritzman-Amir, T., ed., 2015) (in Hebrew).

${ }^{55} \mathrm{Id}$.

${ }^{56}$ Human Rights Watch, "I WANTEd to LiE Down And Die": Trafficking AND Torture of Eritreans in Sudan and Egypt (Feb. 11, 2014), https:// www.hrw.org/report/2014/02/11/i-wanted-lie-down- and-die/trafficking-andtorture-eritreans-sudan-and-egypt.

${ }^{57}$ Population AND ImMigration AUthority, supra note 48.

${ }^{58}$ Kritzman-Amir, T. Introduction, in WHERE LEVINSKI MEETS ASMARA: SOCIAL And Legal Aspects of IsRael's Asylum Policy, supra note 49, at 9, 23-25.

${ }^{59} \mathrm{On}$ the border policy see Kritzman-Amir, T., and Spijkerboer, T., On the Morality and Legality of Borders, 26 HARV. J. HUM. RTs. 1 (2013).

${ }^{60}$ Berman, Y. Detention of Refugees and Asylum Seekers in Israel, inWHERE LeVinski Meets Asmara: Social and Legal Aspects of Israel's Asylum POLICY, supra note 49 , at 147.

${ }^{61}$ Kritzman-Amir, supra note 53, at 23, 33.

${ }^{62} \mathrm{https} / / /$ reliefweb.int/report/israel/israel-forced-and-unlawful-israels-

deportation-eritrean-and-sudanese-asylum-seekers.

${ }^{63}$ Kritzman-Amir, supra note 53 , at 34 .

${ }^{64}$ Reuters, New Tax in Israel Leaves African Migrants Feeling Unwanted and Unwelcome, JeRUSAlem Post (July 3, 2017), https://www.jpost.com/Israel-News/ New-tax-in-Israel-leaves-African-migrants-feeling-unwanted-and-unwelcome498648.

${ }^{65}$ Public Advocacy, Employment, AssAF, http://assaf.org.il/en/node/139 (last visited July 21, 2020).

${ }^{66}$ Kritzman-Amir, supra note 53, at 26.
} 
constantly changing policies ${ }^{67}$. These exclusion mechanisms are deliberate with the goal of deterring asylum seekers from reaching Israel in first place, and deterring those who do reach Israel from staying ${ }^{68}$. As a result, the majority of the asylum seekers are in a liminal situation in which they are physically present but legally absent and, in the foreseeable future, they have no chance of obtaining a stable civil status that will allow them to plan their future, build their lives, or settle down. The Israeli asylum regime has been the subject of critique by the UNHCR, Court, academia, and administrative bodies, among others ${ }^{69}$.

This liminal situation had direct economic implications on the asylum seeking communities even before the pandemic. Not only were asylum seekers struggling to find non-precarious employment due to their status, but they were also facing a financial struggle, mostly due to the so-called "deposit law"70. The law required asylum-seekers to "deposit" one-fifth of their salaries each month with the state and made these salaries available only upon their departure from the country. In addition, under the "deposit law" employers were required to transfer additional 16 percent of the salaries to the deposit - instead of paying an equivalent amount on the benefits they were eligible to receive from their employers according to Israeli employment laws. This imposition on the already-low salaries of asylum seekers has already jeopardized their stability ${ }^{71}$. The constitutionality of this law was challenged by a coalition of human rights organizations in a petition to the Israeli High Court of Justice shortly after the law entered into force in May $2018^{72}$.

But due to massive furloughs and business closures among asylum seekers, poverty approached a scope that could no longer

\footnotetext{
${ }^{67} \mathrm{Paz}$, Y. Ordered Disorder: African Asylum Seekers in Israel and Discursive Challenges to an Emerging Refugee Regime (New Issues in Refugee Research, Research Paper No. 205, 2011), http://www.unhcr.org/research/working/ 4d7a26ba9/ordered-disorder-african-asylum-seekers-israel-discursivechallenges-emerging.html.

${ }^{68}$ Yaron-Mesegene, H. Divide and Conquer Through Order and Disorder: The Politics of Asylum in Israel - Bureaucracy and Public Discourse", in WHERE Levinski Meets Asmara: Social and Legal Aspects of Israel's Asylum POLICY, supra note 49 , at 88.

${ }^{69}$ See, e.g., UNHCR, UNHCR's Position ON THE STATUS OF ERITREAN AND Sudanese Nationals Defined as 'Infiltrators' by Israel, UNHCR 1-2 (Nov. 2017), https://www.refworld.org/docid/5a5889584.html; AdminA 8908/11 Asefu v. The Ministry of Interior, 16 (2011) (opinion of Justice Vogelman); HCJ 7146/12 Adam v. the Knesset, 64(2) PD 717, g 9 (Justice Arbel) (2013); State Comptroller's Annual Report 68c, Chapter 2: On Minister of Interior-The Population and Immigration Authority: The Treatment of Political Asylum Seekers in Israel, 1428 n.19 (May 2018) (in Hebrew), http://www.mevaker.gov. il/he/Reports/Report_627/8eaa80a0-a426-4424-aefa-8fdc4e8b176a/221-zarim-

2.pdf; Where Levinski Meets Asmara: Social and Legal Aspects of ISRAEL'S ASYLUM POLICY, supra note 49.

${ }^{70}$ Law for the Prevention of Infiltration (Offenses and Jurisdictions) (Legislative Amendments and Temporary Order), 5774-2014, SH 2483 p. 84. Following a petition to the High Court of Justice, the Israeli government introduced some easements, allowing to place a more modest amount in the deposits of vulnerable asylums seekers, such as women,s single fathers, the elderly and minors. Migrant Workers' Regulations Types of Cases and Conditions That If Materialized the Infiltrator Migrant Worker Would Be Eligible to Reciee the Deposit Prior to Leaving Israel for a Non-Temporary Exit, 5778-2018, KT No. 8042 p. 2486.

${ }^{71}$ Kritzman-Amir, T., and Rothman-Zecher, K. Mainstreaming Refugee Women's Rights Advocacy, 42 HARV. J. L. \& Gender 501, 546 (2019).

${ }^{72}$ Petition and Amicus Brief in HCJ 2293/17 Ester Tsegay Gresgeher v. Knesset
} (Isr.) (in Hebrew) [on file with author]. be alleviated by community mutual aid mechanisms ${ }^{73}$. Many of them worked in the restaurant industry, which suffered a significant blow when physical distancing requirements were put in place $^{74}$. They were not eligible to many of the welfare benefits which are extended to nationals. Their severance payments were not made available, since, as per the "deposit law," employers transfer severance pay of asylum seekers into the "deposit," even in this situation during which it was clear that leaving Israel is not a viable option in the foreseeable future ${ }^{75}$. Many asylum seekers were struggling to find adequate housing to quarantine in, as many of them lived in overcrowded, poorly ventilated shared spaces $^{76}$. Having lost their employment, they have also lost their health insurance, and were not eligible for services of the national health care system, which, despite its claim to be universal, was limiting services only to citizens and residents ${ }^{77}$.

This crisis in the asylum seeking communities did not go unnoticed. The Israeli government considered in April 2020 relaxing measures of economic pressure to push asylum seekers out of Israel in order to address the emergency situation, but was hesitant to legislate the amended regulations necessary to relieve the pressure off the asylum seeking population, for fear of political dissatisfaction of its base $\mathrm{b}^{78}$. The main concern was that this measure will be perceived as a normalization or acceptance of the presence of asylum seekers in Israel, in contrast to the wide and intensive efforts to exclude them ${ }^{79}$.

As in the past, the Israeli High Court of Justice, became once again an important institution in which migrants' rights NGOs challenge governmental policies. The Court, on the one hand, was well-experienced in judicial review in emergency situations, and, on the other hand, gained reputation (and suffered loss of legitimacy in the Israeli public) for repeatedly nullifying aspects of the immigration policies when those defied constitutional human rights obligations ${ }^{80}$. It is in this particular legal-political climate that the High Court of Justice issued its decision to strike down parts of the "deposit law" as unconstitutionally violating the right to property of asylum seekers in a disproportionate

\footnotetext{
${ }^{73}$ Yaron, L. Without a Room for Isolation or Money for Food: Asylum Seekers Need to Deal Alone With Coronavirus, HAARETz (Mar. 24, 2020), https://www.haaretz. co.il/health/corona/.premium-MAGAZINE-1.8703263. 74

${ }^{75}$ Physicians for Human Rights et al., EFfects of Coronavirus PANDEMIC ON ASYlum SEEKERS IN ISRAEL (2020), https://hotline.org.il/wpcontent/uploads/2020/03/25.3-\%D7\%94\%D7\%A9\%D7\%9C\%D7\%9B\%D7\%95 \%D7\%AA-\%D7\%9E\%D7\%92\%D7\%A4\%D7\%AA-\%D7\%94\%D7\%A7\%D7\%95 \%D7\%A8\%D7\%95\%D7\%A0\%D7\%94-\%D7\%A2\%D7\%9C-\%D7\%9E\%D7\%91 \%D7\%A7\%D7\%A9\%D7\%99-\%D7\%9E\%D7\%A7\%D7\%9C\%D7\%98-.pdf. ${ }^{76} \mathrm{Id}$.

${ }^{77} \mathrm{Id}$.

${ }^{78}$ Zvi Cohen, N. “Give Them Their Money Back”, DAVAR (Apr. 17, 2020), https:// www.davar1.co.il/217962/.

${ }^{79}$ Schleifer, D. Dangerous Coronavirus Grant: Israeli Government Considers Giving Each Infiltrator on Account of Their Return Grant, CHADSHOT HAMESHEK (Apr. 16, 2020), https:/www.meshekil.com/ReadNews/gocpGavpa-\%D7\%90\%D7\%A8 \%D7\%92\%D7\%95\%D7\%A0\%D7\%99-\%D7\%94\%D7\%A9\%D7\%9E\%D7\%90\%D7 \%9C-\%D7\%A0\%D7\%9C\%D7\%97\%D7\%9E\%D7\%99\%D7\%9D-\%D7\%91\%D7 \%A9\%D7\%91\%D7\%99\%D7\%9C-\%D7\%9E\%D7\%A2\%D7\%A0\%D7\%A7\%D7 \%99\%D7\%9D-\%D7\%91\%D7\%A9\%D7\%95\%D7\%95\%D7\%99-\%D7\%90\%D7\%9C \%D7\%A4\%D7\%99-\%D7\%A9\%D7\%A7\%D7\%9C\%D7\%99\%D7\%9D-\%D7\%9C \%D7\%9E\%D7\%A1\%D7\%AA\%D7\%A0\%D7\%A0\%D7\%99\%D7\%9D-.

${ }^{80}$ Weill \& Kritzman-Amir, supra note 14.
} 
manner ${ }^{81}$. In the closing paragraph of her opinion, Chief Justice Hayut, who wrote the majority opinion in this case, mentioned that the Court stands behind its holding as a general matter, but that the pandemic outburst and its economic implications on this disempowered population give additional force to the decision ${ }^{82}$.

This decision thus, stands against the common wisdom, which suggests that courts would be inclined to extend deference to the executive and legislative ${ }^{83}$, and thus would be ineffective guardians of human rights in situations of emergency, fearing loss of legitimacy should they intervene in the management of the crisis ${ }^{84}$. In fact, it seems that it is the emergency that allowed the Court to reach this decision, without fearing loos of legitimacy. Interestingly, the Court's decision received little news coverage and public attention ${ }^{85}$ and thus infringed the Court's legitimacy to a minimal degree. In the last few years the Court has made continuous, seemingly conscious attempts to preserve its legitimacy and appear to be respectful of sovereign decisions in the realm of immigration. In this case, whether intentional or not, it was probably an institutionally solid strategic move on the Court's end to publish the decision in the height of the pandemic. This way, its decisions managed to fly under the radar of the majority of the population in Israel, and - to some extent - the Israeli government and parliament, which were too busy dealing with the pandemic and the constitutional crisis. Additionally, the decision received additional publically-needed justification, in light of the dire situation and the immediate need to alleviate the pressure off the asylum seeking communities. To some extent, the constitutional crisis in Israel and the emergency situation triggered by the pandemic have paradoxically made it possible to protect the rights asylum seekers in an otherwise challenging environment. The bigger questions of the lack of access of asylum seekers to the Israeli welfare state was not fully addressed yet

\footnotetext{
${ }^{81} \mathrm{HCJ} 2293 / 17$ Gersegher vs. the Knesset, g9 32-52 to the opinion of President Hayut, https://supremedecisions.court.gov.il/Home/Download?path= HebrewVerdicts\%5C17\%5C930\%5C022\%5Cv53\&fileName=17022930.V53\& type $=2$.

${ }^{82} I d$. at 61 to the opinion of President Hayut.

${ }^{83}$ DYZEnhaus, D. The Constitution of Law: Legality in a Time of EMERGENCY, 18-19 (2006).

${ }^{84}$ See, e.g., ROSSITER, C., and LongakeR, R. THE SUPREME COURT AND THE COMMANDER-IN-CHIEF 52 (expanded ed. 1976); Cole, D. Judging the Next Emergency: Judicial Review and Individual Rights in Times of Crisis 101 Mich. L. Rev. 2565, 2568-2571 (2003).

${ }^{85}$ See, e.g., Yaron, L. HCJ Instructed the Annulment of Deposit Law That Obliges Asylum Seekers to Withdraw 20\% of Their Paycheck, HAARETZ (Apr. 23, 2020), https://www.haaretz.co.il/news/law/.premium-1.8793832; Grinzaig, A. HCJ Annuled Deposit Law That Obliges Asylum Seekers to Withdraw 20\% of Their Paycheck, GloBEs (Apr. 23, 2020), https://www.globes.co.il/news/article.aspx? did=1001326446; Milman, O. HCJ Annulled Asylum Seekers' Deposit Law, CALCALIST (Apr. 23, 2020), https://www.calcalist.co.il/local/articles/0,7340,L3810354,00.html; Freidson, Y., and Alon, A. HCJ Annuled the Privision of "Deposit Law" That Cuts Infiltrators' Wages to Promote Leaving, Ynet (Apr. 23, 2020), https://www.ynet.co.il/articles/0,7340,L-5719803,00.html; Levy, A. Deposit Law Invalidated: "HCJ Stops Every Attempt to Protect State Sovereignty", MiDA (Apr. 23, 2020), https://mida.org.il/2020/04/23/\%D7\%97\%D7\%95\%D7\%A7-\%D7\%94 \%D7\%A4\%D7\%99\%D7\%A7\%D7\%93\%D7\%95\%D7\%9F-\%D7\%A0\%D7\%A4\%D7 \%A1\%D7\%9C-\%D7\%91\%D7\%92\%D7\%A5-\%D7\%91\%D7\%95\%D7\%9C\%D7 \%9D-\%D7\%9B\%D7\%9C-\%D7\%A0\%D7\%99\%D7\%A1\%D7\%99\%D7\%95\%D7 $\% 9 F-\% D 7 \% 9 C \% D 7 \% 94 /$.
}

by either the government or the Court, and thus asylum seekers continue to struggle even after the decision of the Court.

\section{Palestinians}

On the far end of the spectrum is the most excluded population: Palestinian migrants. Shortly after the 1967 war, during which Israel occupied the West Bank and Gaza, Israel started allowing Palestinians from these occupied territories to come into Israel as frontier workers ${ }^{86}$. While their employment in Israel was often restricted for various political and security related reasons, the ability to employ Palestinians became an important feature of the Israeli economy ${ }^{87}$. Similarly, the income generated from employment in Israel constitutes an important contribution to the Palestinian economy ${ }^{88}$.

For many years, Palestinians who used to reside in what is now Israel prior to its independence and their descendants had a very limited ability to acquire citizenship ${ }^{89}$, since those who fled Israel before or during the 1948 war $^{90}$ were ineligible for citizenship. Perhaps most importantly, the possibility of naturalization for Palestinians and enemy nationals, even for the purpose of family reunification, has been almost completely blocked by temporary legislation, which has been renewed over the course of 18 years, but for rare and exceptional circumstances ${ }^{91}$. Despite judicial challenges to the legislation, it was upheld twice by a slim majority in the Supreme Court ${ }^{92}$.

Palestinians are also most likely to lose their citizenship status, since one of the grounds on which citizenship may be revoked is entering into enemy countries or acquiring citizenship in one of those countries, in which many of the Palestinian citizens of Israel have family ties or other affiliations ${ }^{93}$. Calls for broadening the authority to revoke the citizenship of Palestinians are often heard within the judicial process or the public debate ${ }^{94}$, and the few rare occasions on which citizenship has been revoked involved Palestinian citizens ${ }^{95}$. It should also be noted that

\footnotetext{
${ }^{86}$ Mundlak, G. Power-Breaking or Power-Entrenching Law? The Regulation of Palestinian Workers in Israel, 20 COMP. LABOR L. \& POL'Y J. 569 (1999). ${ }^{87} I d$.

${ }^{88}$ Farsakh, L., Palestinian Labor Migration to Israel: Labour, Land AND OCCUPATION 76-90, 117-41 (2005).

${ }^{89}$ Nationality Law, supra note $35 \$ \$ 3-3 a$.

${ }^{90}$ The question of whether the Palestinians fled Israel voluntarily or whether they were forced to leave by the State of Israel has been well-debated by historians and falls beyond the scope of this paper. See Morris, B., THE BIRTH OF THE Palestinian Refugee Problem, 1947-1949 (1989).

${ }^{91}$ Nationality and Entry into Israel (Temporary Order) Law, 5763-2003, SH 1901 p. 544. The existence of such rare and exceptional circumstances is supposed to be considered by a committee, but such exceptions are rarely recognizaed.

${ }^{92}$ HCJ 7052/03 Adalah-The Legal Center for Arab Minority Rights in Israel v. Minister of Interior, 61(2) PD 202 (2006); HCJ 466/07 M.K. Galon v. Attorney General (2012), https://supremedecisions.court.gov.il/Home/Download? path=HebrewVerdicts/07/660/004/o30\&fileName=07004660_o30.txt\&type=2.

${ }^{93}$ Nationality Law, supra note $35, \$ \$ 11$.

${ }^{94}$ See, e.g., HCJ 2934/07 Israel Law Center v. The Chair Person of The Knesset (2007), https://supremedecisions.court.gov.il/Home/Download? path=HebrewVerdicts/07/340/029/M06\&fileName=07029340_m06.txt\& type=2; HCJ 7803/06 Abu Arfe v. The Minister of Interior (2017), https:// supremedecisions.court.gov.il/Home/Download?path=HebrewVerdicts/06/030/ 078/m42\&fileName $=06078030 . \mathrm{m} 42 \&$ type $=2$.

${ }^{95}$ Letter from Adv. Oded Feller, Association of Civil Rights in Israel, to the Legal
} Advisor of the Ministry of Interior 6 (Jan. 10, 2007) (on file with author). 
a significant number of Palestinians do not have citizenship status, but rather hold an inferior residency status, which they can easily lose if they relocate, even temporarily, to another country $^{96}$ and which carries only limited rights and partial participation in the Israeli welfare state. To put it differently, Israel's immigration and citizenship regime are engaged in the exclusion and "othering" Palestinians ${ }^{97}$.

When it comes to migration for employment, Palestinians - as frontier workers - are even more excluded than the other migrant workers, as they are not eligible for some of the (few) rights protections that are afforded to migrant workers and expected to receive them at their homes. It is therefore interesting how Israel approached the issue of employment of Palestinians during the Coronavirus outbreak. At the peak of the pandemic outbreak, when Israelis were asked to shelter in place and borders were by and large closed, Israel imposed a closure on the West Bank and $\mathrm{Gaza}^{98}$. It also placed restrictions on Palestinian workers, allowing them to continue working in Israel but prohibiting their return to their homes for several weeks at a time ${ }^{99}$. To some extent, the prohibition to return home turned Palestinian frontier workers to migrant workers and was somewhat counterintuitive. It ran against the decades of efforts to exclude Palestinian workers and make them as temporary, as excluded and as disposable as possible. Yet this measure allowed for Palestinians to have a longer presence than usual in Israel. Aiming to protect the Israeli public, this step also protected the Palestinians, who reported that a significant number of those tested positive for COVID19 contracted the virus during their employment in Israel ${ }^{100}$. At the same time, this forced people to make a tough choice between providing for their families or staying with them in a tense and challenging time. Additionally, the requirement from Palestinian workers to remain in Israel was not accompanied by any form of inclusion in the Israeli welfare state. Thus, amidst this global health crisis, Palestinians were not offered either access to the national healthcare system, nor were their employers required to provide health insurance for them ${ }^{101}$. The result was that Palestinians who were suspected to have contracted the virus had no recourse in Israel, and were dumped by their Israeli employers, in an act triggered by fear and disregard, next to checkpoints, at the hope that they would be picked up

\footnotetext{
${ }^{96}$ See, e.g., Adm.Pet. (Jerusalem) 384/07 Siaj v. The Minister of Interior (2008) (regarding the loss of residency of a person who left Israel to study abroad); Adm.Pet. (Jerusalem) 247/07 Omri v. The Minister of Interior (2010) (regarding the loss of residency of a person who left Israel to live with a spouse in his country of citizenship and wanted to regain his residency following the divorce).

${ }^{97}$ Kritzman-Amir, supra note 41.

${ }^{98}$ Petition in HCJ 2730/20 Kav Laoved V. The Ministry of Health, 24 (Apr. 28, 2020) (in Hebrew, on file with author).

${ }^{99}$ Update Notice for Employers of Palestinian Workers in Agriculture in Light of the Coronavirus Crisis, Ministry OF AgriCulture AND RuRAL DEVELOPMENT (June 28, 2020), https://www.moag.gov.il/subject/covid19/Pages/ palestinian_worker.aspx; Rasheed, Z., et al., WHO Reports Record Daily Surge in Global Coronavirus Cases: Live, AL JAZEerA (July 10, 2020), https://www. aljazeera.com/news/2020/07/mexico-south-africa-post-record-coronaviruscases-live-updates-200710000611381.html.

${ }^{100}$ Rasheed et al., supra note 92.

${ }^{101}$ Petition in HCJ 2730/20 Kav Laoved V. The Ministry of Health, gg 1-8 (Apr. 28, 2020) (in Hebrew, on file with author).
}

by Palestinian ambulances ${ }^{102}$. Additionally, employers were not held to any significant standard regarding the type of housing they need to provide, and the immediate result was that workers often resided in their work places ${ }^{103}$. Generally speaking, there was no authority overseeing the employment conditions and access to rights of Palestinians workers in this tense time ${ }^{104}$.

This practice was challenged in a petition to the Israeli High Court of Justice, requiring that Palestinian workers be provided adequate housing, health insurance ${ }^{105}$. Additionally, the petition required monitoring of the conditions of the Palestinian employees ${ }^{106}$. In response to the petition, the government issued emergency regulations, requiring provision of health insurance, setting clear guidelines for physical distancing and adequate housing standards ${ }^{107}$. In addition, employers were instructed to refrain from confiscating identity documents of their employees, which was previously required, allegedly by mistake, since it is illegal according to Israeli law ${ }^{108}$. Nevertheless, it seems that enforcement of these regulations is partial at best, and Palestinians continue to face difficult challenges during their employment in Israel $^{109}$.

\section{CONCLUSION}

This paper is written as the number of persons tested positive for the Coronavirus is rapidly increasing in Israel. Though initially able to respond quickly and "flatten the curve" in the spring of 2020, Israel has become quite vulnerable to the pandemic come summer $2020^{110}$.

It is often true that through examination of immigration policy - a policy directed at vulnerable persons on the edge of society - we learn a lot about the society as a whole. It is also true

${ }^{102}$ Al-Waara, A. 'They Dumped Him Like Trash': Palestinian with Suspected Coronavirus Symptoms Thrown Out of Israel, MIDDlE EAST EyE (Mar. 23, 2020), https://www.middleeasteye.net/news/coronavirus-palestine-labourerfound-near-west-bank-checkpoint-covid19.

${ }^{103}$ Yaron, L., and Shezaf, H., While the Public is at Home, Construction Workers Are Sent to Work - Unprotected, HAARETz (Mar. 19, 2020), https://www.haaretz. co.il/health/corona/MAGAZINE-1.8689671; Ayyub, R. Palestinian Workers Find Temporary Israeli Abodes in Coronavirus Crisis, REUTERS (Mar. 23, 2020), https:// www.reuters.com/article/us-health-coronavirus-israel-palestinian/palestinianworkers-find-temporary-israeli-abodes-in-coronavirus-crisis-idUSKBN21A2BS. ${ }^{104}$ Shezaf, H. Israel Doesn't Oversee Palestinian Workers' Health Amid Coronavirus, HAARETZ (Apr. 20, 2020), https://www.haaretz.com/israel-news/.premiumisrael-doesn-t-oversee-palestinian- workers-health-amid-coronavirus- 1.8783881. ${ }^{105}$ Petition in HCJ 2730/20 Kav Laoved V. The Ministry of Health (Apr. 28, 2020) (in Hebrew, on file with author).

${ }^{106} \mathrm{Id}$.

${ }^{107}$ Emergency Regulations (Novel Coronavirus) (Medical Insurance and Adequate Housing for Workers from the Territories), 5780-2020, KT 8536.

${ }^{108}$ Ministry of Agriculture and Rural DeVelopment, Important Update Notice FOR EMPloyers OF PALESTINIAN WORKERS IN Agriculture in Light of the Coronavirus Crisis 3 (2020), https:// www.moag.gov.il/subject/covid19/Documents/update_palastinian_workers.pdf. ${ }^{109}$ Hasson, N. Garbage Recycling Factory in Jerusalem Forced Palestinian Workers to Sleep in Its Territory in Fear of Lockdown, Haaretz (July 14, 2020), https://www.haaretz.co.il/health/corona/.premium-1.8991956?fbclid= IwAR1P1wuqm7azZtDkfliZf-BhVe4HCnymo_k2Z_C452KbOH-2SqoIikG_SVY. ${ }^{110}$ Kershner, I. After Early Success, Israel's Netanyahu Faces Fury for Flubbing Virus Fight, New York Time (July 24, 2020), https://www.nytimes.com/2020/07/ 24/world/middleeast/israel-virus-protests- netanyahu.html. 
that we can learn a lot about a society by looking at its operation in crisis mode. Both of those elements are demonstrated in this paper. The pandemic management did not focus on immigration, but inevitably touched it. It touched it in a way that to some extent builds on the existing approach to the different categories of migrants. Arrival or even expression of desire to arrive of Jewish migrants was celebrated, despite the lack of data on the scope of the phenomenon, and even though some of those arriving were sick or on the brink of destitution - and to some extent because of that. This was seen as a fulfillment of the raison d'etre of the state of Israel - to be a home for the Jewish population of the world. Absorption agencies were prepared, planning for those arrivals. Israel seemed willing to pay a public health and economic price for allowing the arrival of additional Jewish immigrants.

The treatment of non-Jewish migrants was impacted by the government through a different sort of calculus, with a single focus on the immediate, over-simplified perception of utility to the Israeli employers and the Israeli economy, and little attention to the needs and rights of the migrants. Emergency regulations and responses were hastily done, without sufficient thought given to their broad implications. Thus, migrant workers were required not to leave the nursing homes they work in out of concern for their employer, and in an effort to prevent spread of the virus in nursing homes, but without sufficient thought to the psychological impact of such restriction, and how that would impact the quality of care provided to the elderly employers. Only a negotiation with the migrants' rights NGOs brought to an easement of the restrictions. Negotiations with employers ended up with gradually opening possibilities for migrant workers to return to working in Israel or to arrive to work in Israel for the first time.

Asylum seekers were largely neglected, untouched, and forced to be self-sufficient in a situation in which they had no access to employment. Their neglect in this difficult situation was challenging for the communities, and ultimately backfired as their inability to shelter-in-place in an adequate manner translated into growing number of contractions of COVID-19 in the asylum seeking communities ${ }^{111}$.

Palestinian workers were required to almost immediately make a decision to stay in Israel in order to continue their work, but no adequate thought was given to their safety or health situation, or to the issue of their need for housing. In this case too, the negotiations with the NGOs and the pressure of a Court decision resulted in the enactment of regulations to address all of these matters. This oversight was perhaps a result of the constitutional crisis in Israel, or just a result of the many challenges of managing this situation. But to some extent, this oversight reflects the perception of non-Jewish migrants in terms of their labor market contribution, rather than in terms of their complex, rich and demanding humanity.

Through the management of the pandemic, the volatile nature of Israeli immigration policy was exposed. It is a

\footnotetext{
${ }^{111}$ Bar-Tuvia, S., and Drori Avraham, A. There Is a Responsible Body for the Rise in Coronavirus Among Asylum Seekers, YNET (June 14, 2020), https://www.ynet.co.il/ articles/0,7340,L-5747284,00.html.
}

policy formed in response to pressures from employers, NGOs and Courts, in a dispersed, incoherent manner. In a country that does not have a codified immigration law, this is a well-expected and well-known dynamics. Interests in exclusion were sometimes outweighed by economic, religious, and health considerations, whereas in other time they weren't. Most of the decisions were done absent a public debate, through regulations, memorandums and procedures, without parliamentary supervision. The responsive, erratic, changes immigration policy occurred in a time in which predictability and organization were crucial for economic planning in a crushed economy; human rights preservation in a country undergoing a constitutional crisis; and public health management in a world dealing with a global pandemic, and are a cause for concern.

At the same time as the policies during the pandemic have thus far been in line with those taken with respect to the different groups of migrants, the pandemic presented to be an opportunity to alter some fundamentals of the Israeli immigration regimes. In its shadow, the Court felt confident enough to strict down the unconstitutional "deposit law," which also violated asylum seekers rights under international law, without suffering from a significant loss of legitimacy. Additionally, the pandemic brought a historic change to the employment patterns of Palestinians in Israel, turning frontier workers to migrant workers and allowing them some access to the Israeli welfare state. It remains to be seen to what extent some of those alterations will institutionalize for the long-term.

\section{DATA AVAILABILITY STATEMENT}

The original contributions presented in the study are included in the article/supplementary materials, further inquiries can be directed to the corresponding author/s.

\section{AUTHOR'S NOTE}

Visiting Assistant Professor, Boston University School of Law (2020-2021); Visiting Associate Professor, Harvard University Department of Sociology (2018-2021); Senior Lecturer, The College of Law and Business, Israel. LL.B and Ph.D., Tel Aviv University School of Law, Israel. I am grateful to the feedback provided by the reviewers of this paper, the editor of this volume, and Prof. Daphne Hacker. As always, I am thankful for the thorough editing of Dr. Keren Yalin-Mor. The description in this paper reflects the changes in immigration policies which took place until the submission of this paper, in August 2020

\section{AUTHOR CONTRIBUTIONS}

The author confirms being the sole contributor of this work and has approved it for publication. 


\section{FUNDING}

Part of a COVID19 Research Topic. This article is fully waived.

Conflict of Interest: The author declares that the research was conducted in the absence of any commercial or financial relationships that could be construed as a potential conflict of interest.
Copyright (C) 2021 Kritzman-Amir. This is an open-access article distributed under the terms of the Creative Commons Attribution License (CC BY). The use, distribution or reproduction in other forums is permitted, provided the original author(s) and the copyright owner(s) are credited and that the original publication in this journal is cited, in accordance with accepted academic practice. No use, distribution or reproduction is permitted which does not comply with these terms. 